\title{
Pengaruh Metode Latihan dan Koordinasi Mata-tangan Terhadap Keterampilan Smash Bulutangkis
}

\author{
Ella Anugrarista ${ }^{1}$, Arisman $^{2}$ \\ Program Studi Pendidikan Jasmani Kesehatan dan Rekreasi, STKIP Pamane \\ Talino Ngabang, Jalan Afandi Rani Komplek Bali Permai, Ngabang Kab. \\ Landak,79354. Indonesia \\ Email : Ellaanugrarista@gmail.com ${ }^{1}, \underline{\text { Arism199@gmail.com }}{ }^{2}$
}

\begin{abstract}
Abstrak
Tujuan dari penelitian ini adalah untuk mengetahui pengaruh dari metode latihan drill dan metode latihan taktis dan koordinasi mata-tangan terhadap keterampilan smash bulutangkis. Penelitian ini dilakukan pada atlet bulutangkis Sekolah Bulutangkis Camp 43 Pontianak, penelitian ini menggunakan treatmen by level $2 \times 2$. Sampel terdiri dari 32 atlet yang dibagi menjadi 2 kelompok, masing-masing terdiri dari 16 atlet. Teknik analisis data adalah analisis varianas dua jalur ( ANOVA) dan selanjutnya dilanjutkan dengan uji Tuckey pada signifikansi pada tingkat signifikansi $\alpha=0,05$. Hasil penelitian ini menunjukkan bahwa (1) metode latihan drill memiliki pengaruh yang lebih baik daripada metode latihan taktis terhadap keterampilan smash bulutangkis. (2) terdapat interaksi antara metode latihan drill dan metode latihan taktis dan koordinasi mata-tangan terhadap keterampilan smash bulutangkis. (3) metode latihan drill memiliki pengaruh yang lebih baik daripada metode latihan taktis yang memiliki koordinasi mata-tanggan tinggi. (4) metode latihan drill memeiliki pengaruh yang lebih baik darpada metode latihan taktis yang memiliki koordinasi mata-tangan rendah.
\end{abstract}

Kata Kunci : Metode Drill dan Taktis, Koordinasi Mata-tangan, Smash Bulutangkis

\section{THE EFFECT OF EXERCISE MENTHODS AND EYE- HAND COORDINATION SKILL TO BADMINTON SMASH}

\begin{abstract}
The purpose of this research was to determine the effect of the drill training methods and tactical training methods and hand-eye coordination skills to badminton smash. Research was done on badminton athletes at Badminton School Camp 43 Pontianak, this study used treatments by level $2 x 2$. The sample consisted of 32 athletes were divided into 2 groups, each group has of 16 athletes . The data analysis technique is a two-lane varianas analysis ( ANOVA) and then followed by Tuckey test at a significance level of significance at $\alpha=0,05$. The results of this research indicate that ( 1 ) drill exercise methods has a better effect than tactical training methods to badminton smash skills ( 2 ) there is interaction between drill training methods and tactical training methods and hand-eye coordination skills to badminton smash, ( 3 ) exercise drill methods has a better effect than tactical training methods that have high eye-hand coordination.( 4 ) drill exercise method has a better effect than tactical training methods that have low eye-hand coordination.
\end{abstract}


Keyword : Drill and Tactical Methods, eye - hand coordination , Badminton smash

\section{PENDAHULUAN}

Pembinaan bulutangkis dapat diketahuiharus mempunyai beberapa kemampuan, penguasaan dalam keterampilanbulutangkis.Keterampilan ini dapat berupa teknik dan taktik. Dapat disadarai bahwa proses pembinaan yang ada di setiap daerah berbeda-beda., baik dari sumber daya manusia, program latihan, fasilitas latihan dan pendanaan. Dengan demikian untuk menghasilkan suatu hasil yang baik, harus dapat memprioritaskanpembinaan yang lebih baik.

Bulutangkis merupakan salah satu cabang olahraga yang sangat digemari dan sangat populer di dunia termasuk Indonesia. Olahraga ini dapat menjadikan ajang dalam mempersatu bangsa. Selain sebagai alat mempersatu bangsa, bulutangkis ini juga dapat diajdikan ajang, dimana olahraga ini dapat dipertandingan guna mengukur kemampuan apa yang telah dilatih selama mengikuti latihan.

Dalam bulutangkis sangat dibutuhkan penguasaan keterampilan dan teknik bahkan taktik. Keterampilan taktik, keterampilan maupun teknik merupakan satu kesatuan yang dapat dipisahkan. Dengan kemajuan IPTEK pada zaman sekarang, dapat diketahui bahwa dengan IPTEKsemakin komplek pula cabang olahraga tertentu, terutama untuk cabang olahraga bulutangkis.

Untuk mewujudkan harapan dalam peningkatan kualitas dan produktifitas dalam peningkatan perkembanagan prestasi bulutangkis. Banyak sekali hal-hal yang perlu diperhatikan, apalagi dengan penurunan prestasi yang terjadi sekarang. Dapat diketahui prestasi olahraga sekarang sangatlah menurun. Seperti yang di dalam cabang olahraga bulutangkis dalam meningkatkan keterampilan smash bulutangkis khususnya pada Sekolah Bulutangkis DangauLandak (dibawah usia) 16 tahun. Kegiatan latihan bulutangkis pada Sekolah Bulutangkis DangauLandak telah berjalan sesuai dengan program latihan yang telah dibuat oleh pelatih, akan tetapi peningkatan pembina kegiaatan tersebut belum banyak dirasakan, hal inidapat dilihat pada saat atlet tersebut melakukan materi latihan bermain, dimana atlet kurang mampu dalam menempatkan shuttlecock di daerah yang susah dijangkau oleh lawan.

Masalah utama dalam proses latihan dalam pelaksaan latihan smash bulutangkis masih belum efektif. Ini dapat dilihat dari kualitas hasil latihan, selain ini keterampilan smash bulutangkis yang baik, pelatih harus mempunyai berbagai metode latihan yang sekiranya dapat ia terapkan dalam melakukan latihan dan dapat tercapai sesuai tujuan. Dengan penyampaian atau dalam praktek dilapangan yang tepat akan memperbesar minat atlit sehingga tercapai hasil latihan optimal.

Unsur penunjang yang lain dalam melakukan keterampilan smash adalah adanya unsur koordinasi yang baik antara semua unsur-unsur gerakan. Apabila ketepatan dan kecepatan yang dimilki oleh pemain tanpa koordinasi gerakan yang baik akan menjadi sulit menghasilkan sebuahdaya ledak tinggi dalam melakukan keterampilan smash. Dalam pertandingan, banyak sekali melakukan kesalahan dalam melakukan smash bulutangkis, sehingga hasilnya tidak maksimal. Seperti yang dialami di Sekolah Bulutangkis DangauLandak, banyak sekali melakukan kekalahan dalam pertandingan. Oleh sebab itu Sekolah Bulutangkis DangauLandakberusaha berbenah diri dalam penguasaan dengan baik dan benar dalam teknik dasar keterampilan smash bulutangkis.

Untuk mencapai prestasi dalam setiap cabang olahraga, tentu mempunyai standar-standar kriteria latihan-latihan 
terhadap cabang olahraga yang ditekuni, sehingga di dalam pembinaan dan pengembangan atlit nantinya menciptakan para atlet-atlet yang handal khususnya atlet Sekolah Bulutangkis DangauLandak.

Di tengah- tengah tantangan yang dirasakan saat ini, para pelatih bulutangkis , perlu mengampilan peran yang lebih optimal, hal ini dikarenakan untuk meningkatkan prestasi atlit. Salah satu yang perlu dilakukan adalah melakukan latihan yang berkualitas bagi anak-anak khususnya Sekolah Bulutangkis DangauLandak.

\section{METODE}

Metode yang digunakan dalam
penelitian ini adalah metode eksperimen.Metode ini bersifat menguji (validation) yaitu menguji pengaruh satu atau lebih variabel terhadap variabel lain. Metode eksperimen adalah metode penelitian yang digunakan untuk mencari pengaruh treatment (perlakuan) tertentu.Dalam penelitian ini terdapat tiga variabel, yakni : (1) variabel bebas adalah metode latihan drill dan metode latihan taktis (2) Variabel terikat adalah keterampilan smash bulutangkis, dan (3) variabel atribut yaitukoordinasi matatangan. Desain penelitian atau rancangan penelitian adalah rencana dan struktur penyelidikan yang disusunsedemikian rupa sehingga peneliti akan memperoleh jawaban untuk penyataan-pernyataan penelitian.

$$
\text { Desain penelitian ini }
$$

menggunakan rancangan treatmen by level $2 \mathrm{x}$. rancangan treatmen adalah unit-unit eksperimen ke dalam sel relatif bersifat homogen. Secara visual desain penelitian ini dapat digambarkan sebagai berikut :

Pada Penelitian ini tempat dan waktu penelitian yang digunakan adalah Lapangan Bulutangkis Dangau Landak Jalan Sungai Buluh, Ngabang. Penelitian ini dilakukan pada tanggal 30 januari sampai 30 februari tahun 2018.Populasi yang dilibatkan dalam penelitian ini adalah Sekolah Bulutangkis DangauLandakUsia
16 Tahun. Adapun untuk sampel penelitian yaitu seluruh populasi terjangkau dijadikan sampel penelitian (total sampling). Populasi target dalam penelitian ini adalah seluruh atlet Sekolah Bulutangkis DangauLandakUsia 16 Tahun yang berjumlah 32 orang. Petugas Tes Terdiri dari :Tiga orang, satu sebagai pelatih, 2 sebagai pencatat saat melakukan tes.

Dalam penelitian ini koordinasi matatangan di operasikan menjadi 2 (dua) kategori, yaitu koordinasi mata-tangan tinggi dan koordinasi mata-tangan rendah, kemampuan interaksi gerak ini diharakan dapat memberikan interaksi dengan variabel-variabel lainnya terhadap peningkatan koordinasi mata-tangan atlet Sekolah Bulutangkis DangauLandak.

Pelaksanaan

Tes

koordinasimatatangan:Atlet melakukan lemparan yang berjarak $2 \mathrm{~m}$ dari tempat sasaran yang telah ditentukan.Atlet akan mendapatkan nilai 1 jika lemparan yang dilakukan masuk ke daerah sasaran, dan 0 jika bola tidak masuk ke daerah sasaranLemparan akan dilakukan sebanyak 10 kali.

Alat-alat yang digunakandalammelakukanTesKoordinasi Mata-

Tanganadalahsebagaiberikut:Satubuah bola tenis, Dindingtepatsasaranlemparan, Kapursebagaipenggaris, Stopwatch untukmengukurwaktupelaksanaan

,Meteran, Blangkopenilaian, Pena sebagaialattulis

Pelaksanaantessmash bulutangkis :sampelberdiri di tengah-tengahlapangan, pengumpanberdiridilapanganlawanmembe rikanumpanlambungkepadatesteetepatpada pukulansmash forehandsebanyak 20 kali, 10 kali sebelahkanan, 10 kali sebelahkiri. Testeemelakukan smash di daerahlawandengansasaranpukulan smash yang sudahbernilai 4,3,2,1. Dan timmenilaibertugasmencatatnilaidimanada erahshuttlecookjatuh. 
Alat-alat yang digunakanadalah, lapanganbulutangkis, shuttlecook, spidol/ kapur, blankopenilaian.

. Untuk menganalisa data yang terkumpul, digunakan teknik analisis varians (ANAVA) dua arah pada taraf signifikan $\alpha=0,05$. Persyaratan yang diperlukan dalam analisis varians adalah uji normalitas dan homogenitas. Uji normalitas menggunakan uji Lillefors. Sedangkan untuk uji homogenitas menggunakan uji Bartlet. Apabila terdapat interaksi akan dilanjutkan dengan uji Tukey.

\section{HASIL DAN PEMBAHASAN \\ HasilPenelitian}

Hasil analisis gerak diatas diperkuat hasil analisis varian (ANAVA) pada taraf signifikan $\alpha=0,05$, di dapat $\mathrm{F}_{\mathrm{o}}=$ 4,505 dan $F_{t}=4,00$ DengandemikianF $F_{0}>$ $\mathrm{F}_{\mathrm{t}}$, sehinggaH $\mathrm{H}_{\mathrm{o}}$ ditolak, sehinggadapatdisimpulkanbahwasecarakes eluruhan, terdapatperbedaan yang nyataantarametodelatihandrilldaripadamet odelatihantaktisdalamdistribusiterhadapket erampilansmash bulutangkis.Dengan demikian beradasarkan pembahasan hasil penelitian, maka metode latihan drill lebih cocok diterapkan dalam meningkatkan keterampilan smash bulutangkis.

Hasil analisis varian2x2, tentang interaksi antara metode latihan dengan koordinasi mata-tangan terhadap keterampilan smash bulutangkis menunjukkan bahwa Fo interaksi $(\mathrm{FAB})=$ 10,630 dan $F$ tabel $=4,00$. Tampak bahwa $\mathrm{F}$ hitung $>\mathrm{F}$ tabel, sehingga $\mathrm{H}_{0}$ ditolak. dan $\mathrm{H}_{1}$ diterima. Dengan demikian dapat disimpulkan bahwa terdapat interaksi antara metode latihan dan koordinasi mata-tangan terhadap keterampilan smash bulutangkis.

Untuklebihjelasnyadapatdilihatdal amtabelberikut. 
Tabel1.Rangkuman Data Hasil Penelitian

\begin{tabular}{|c|c|c|c|c|c|c|}
\hline $\begin{array}{ll}\text { Koordinasi } \\
\text { mata } \\
\text { tangan }\end{array}$ & (Dri & ) $A_{1}$ & (Ta & tis) $\mathrm{A}_{2}$ & & \\
\hline (Tinggi) $B_{1}$ & $\begin{array}{l}\mathrm{n}_{1}= \\
\sum \mathrm{X}_{1}= \\
\sum \mathrm{X}_{1}^{2}= \\
\mathrm{X}_{1}= \\
\left(\sum \mathrm{X}_{1}\right)^{2}=\end{array}$ & $\begin{array}{l}16 \\
486 \\
15354 \\
30,38 \\
236196 \\
\end{array}$ & $\begin{array}{l}\mathrm{n}_{2}= \\
\sum \mathrm{X}_{2}= \\
\sum \mathrm{X}_{2}^{2}= \\
\mathrm{X}_{2}= \\
\left(\sum \mathrm{X}_{1}\right)^{2}\end{array}$ & $\begin{array}{l}16 \\
363 \\
8641 \\
22,69 \\
=131769 \\
\end{array}$ & $\begin{array}{l}\mathrm{n}_{\mathrm{b} 1}= \\
\sum \mathrm{X}_{\mathrm{b} 1}= \\
\sum \mathrm{X}_{\mathrm{b} 1}{ }^{2}= \\
\mathrm{X}_{\mathrm{b} 1}= \\
\left(\sum \mathrm{X}_{\mathrm{b} 1}\right)^{2}=\end{array}$ & $\begin{array}{l}32 \\
849 \\
23995 \\
26,53 \\
720801 \\
\end{array}$ \\
\hline (Rendah) $\mathrm{B}_{2}$ & $\begin{array}{l}\mathrm{n}_{3}= \\
\sum \mathrm{X}_{3}= \\
\sum \mathrm{X}_{3}^{2}= \\
\mathrm{X}_{3}= \\
\left(\sum \mathrm{X}_{3}\right)^{2}=\end{array}$ & $\begin{array}{l}16 \\
355 \\
8243 \\
22,19 \\
126025 \\
\end{array}$ & $\begin{array}{l}\mathrm{n}_{4}= \\
\sum \mathrm{X}_{4}= \\
\sum \mathrm{X}_{4}^{2}= \\
\mathrm{X}_{4}= \\
\left(\sum \mathrm{X}_{4}\right)^{2}=\end{array}$ & $\begin{array}{l}16 \\
381 \\
9667 \\
23,81 \\
145161 \\
\end{array}$ & $\begin{array}{l}\mathrm{n}_{\mathrm{b} 2}= \\
\sum \mathrm{X}_{\mathrm{b} 2}= \\
\sum \mathrm{X}_{\mathrm{b} 2}^{2}= \\
\mathrm{X}_{\mathrm{b} 2}= \\
\left(\sum \mathrm{X}_{\mathrm{b} 2}\right)^{2}\end{array}$ & $\begin{array}{l}32 \\
736 \\
17910 \\
23,00 \\
541696 \\
\end{array}$ \\
\hline Total & $\begin{array}{l}\mathrm{n}_{\mathrm{k} 1}= \\
\sum \mathrm{X}_{\mathrm{k} 1}= \\
\sum \mathrm{X}_{\mathrm{k} 1}^{2}= \\
\mathrm{X}_{\mathrm{k} 1}= \\
\left(\sum \mathrm{X}_{\mathrm{k} 1}\right)^{2} \\
=\end{array}$ & $\begin{array}{l}32 \\
841 \\
23597 \\
26,28 \\
707281\end{array}$ & $\begin{array}{l}\mathrm{n}_{\mathrm{k} 2}= \\
\sum \mathrm{X}_{\mathrm{k} 2}= \\
\sum \mathrm{X}_{\mathrm{k} 2}{ }^{2}= \\
\mathrm{X}_{\mathrm{k} 2}= \\
\left(\sum \mathrm{X}_{\mathrm{k} 2}\right)^{=}\end{array}$ & $\begin{array}{l}32 \\
744 \\
18308 \\
23,25 \\
553536\end{array}$ & $\begin{array}{l}\mathrm{n}_{\mathrm{t}}= \\
\sum \mathrm{X}_{\mathrm{t}}= \\
\sum \mathrm{X}_{\mathrm{t}}^{2}= \\
\mathrm{X}_{\mathrm{t}}= \\
\left(\sum \mathrm{X}_{\mathrm{t}}\right)^{2}=\end{array}$ & $\begin{array}{l}64 \\
1585 \\
41905 \\
24,77\end{array}$ \\
\hline
\end{tabular}

Sebaliknya, metode latihan taktis sama-sama dapat diterapkan bagi atlet yang memiliki koordinasi mata-tangan rendah. Hal ini diperkuat oleh hasil uji lanjut yang membedakan antara metode latihan drill dengan yang memiliki koordinasi matatangan tinggi dan metode latihan taktis dengan yang memiliki koordinasi matatangan tinggi. Dengan kata lain keefektifan metode latihan drill dengan koordinasi mata-tangan tinggi lebih baik secara nyata dibandingkan dengan metode latihan taktis. Dengan kata lain metode latihan taktis dan metode latihan drill keduanya sama-sama memberikan keefektifan hasil terhadap keterampilan smash bulutangkis.

Dikatakan bahwa kedua metode ini mempunyai tujuan yang sama yaitu meningkatkan keterampilan smash bulutangkis, tetapi masing-masing memiliki perbedaan dalam segi hasilnya. Bagi atlet yang memiliki koordinasi mata- tangantinggi hal yang demikian justru akan dapat mengembangkan keterampilannya terhadap pencapaian peningkatan keterampilan, karena mereka lebih tertarik untuk melakukan yang lebih jauh.

Metode latihan Drill dalam pelaksanaannya, dengan cara pengulangan latihan dengan tujuan untuk meningkatkan atau menguasai teknik dasar yang akan dilatih, sedangkan metode latihan Taktis dalam pelaksanaannya, menekankan pada mencari pemecahan dan mengambil keputusan yang tidak terlalu sulit atau mudah. Dengan kata lain atlet yang melakukan metode latihan Taktis tidak dipengaruhi oleh faktor eksternal.

Bagi atlet yang memiliki keterampilan gerak tinggi, latihan tersebut merupakan kegiatan yang biasa serta tidak mempunyai tantangan yang tinggi, karena menurutnya latihan tersebut sangat mudah dan sederhana sehingga tidak menimbulkan keterampilan yang tinggi serta unsur 
kompetisi sangat kecil dalam meningkatkan keterampilan smash bulutangkis, dengan demikian hasil yang akan dicapai juga tidak seperti yang diharapkan. Dengan kata lain, berlatih dengan penerapan metode latihan Taktis bagi atlet yang memiliki kekuatan koordinasi mata-tangan tinggi kurang menimbulkan semangat dan kompetisi.

Kelompok koordinasi mata-tangan tinggidengan metode latihan Drill $\left(\mathrm{P}_{3}\right)$ dibanding dengan kelompok koordinasi mata-tangan tinggidengan metode latihan Taktis $\left(\mathrm{P}_{4}\right)$, diperoleh $\mathrm{Q}_{\mathrm{h}}=5,38^{*}$ dan $\mathrm{Q}_{\mathrm{t}}=$ 3,65. Dengan demikian $\mathrm{Q}_{\mathrm{h}}$ lebih besar dari $\mathrm{Q}_{\mathrm{t}}$, sehingga Ho ditolak.

\section{Pembahasan}

Berdasarkan pembahasan hasil penelitian, maka dapat direkomendasikan bahwa bagi atlet yang memilki koordinasi mata-tangan tinggi, metode latihan Drill lebih cocok diterapkan dalam meningkatkan keterampilan smash bulutangkisdibandingdenganmetodelatihant aktis.

Dikatakan bahwa kedua metode latihan ini mempunyai tujuan yang sama yaitu meningkatkan keterampilansmash bulutangkis, tetapi masing-masing memiliki perbedaan dalam segi pelaksanaannya dan memilikiperbedaandalamsegihasilnya.

Metode latihandrill dalam pelaksanaannya, dengan cara pengulangan latihan dengan tujuan untuk meningkatkan atau menguasai teknik dasar yang akan dilatih, sedangkan metode latihan taktis dalam pelaksanaannya, menekankan pada mencari pemecah suatu masalah dan mengambil keputusan yang tidak terlalu sulit atau mudah.

\begin{tabular}{ll}
\multicolumn{1}{c}{ Berdasarkanhipotesis } & yang \\
telahdiujikebenarannya, & \\
makadapatdiuaraikansebagaiberikut & $: \quad 1)$
\end{tabular} secarakeseluruhanketerampilan smash bulutangkismelaluimetodelatihanlebihbaikd ari pada metodelatihantaktis. dalamketerampilansmash bulutangkis, metodelatihan yang digunakanmempunyaitujuan yang samayaitumeningkatkanketerampilan smash bulutangkis yang mana koordinasimatatangansangatmenunjanguntukmendapatkanh asilketerampilan smash bulutangkis yang baik, akantetapimasingmasingmetodelatihantersebutmemilikiperbe daandalamsegihasilnya.

Makadapatdirekomendasikanbahwametodel atihan drill lebihcocokditerapkandalammeningkatkanke terampilan smash bulutangkis. 2) Terdapat interaksi antara metode latihan dengan Koordinasi mata-tangan terhadap keterampilan smash bulutangkis. Hal inidikuatkandenganhasilanalisisvarians $2 \times 2$, tentanginteraksi antara metode latihan dengan Koordinasi mata-tangan terhadap keterampilan smash bulutangkis menunjukkan bahwa $\mathrm{F}$ hitung > F tabel, sehingga $\mathrm{H}_{0}$ ditolak. dan $\mathrm{H}_{1}$ diterima. Dengan demikian dapat disimpulkan bahwa terdapat interaksi antara metode latihan dan Koordinasi mata-tangan terhadap keterampilan smash bulutangkis.3)Bagi atlet yang memiliki koordinasi mata-tangan tinggi, keterampilan smash bulutangkismelalui penerapan metode latihan drill lebih baik daripada metode latihan taktis.4) Terdapat perbedaan keterampilan smash bulutangkis antara metode latihan drill dengan koordinasi mata-tangan rendah dan metode latihan taktis dengan koordinasi mata-tangan rendah pemain bulutangkis pada Sekolah Bulutangkis DangauLandak.

Dengan demikian, berdasarkan pembahasan hasil penelitian, metodelatihan drill sangatcocokuntukdilakukandalamketerampi lan smash bulutangkis. Karena untukmeningkatkanketerampilan smash bulutangkisdibutuhkanlatihan yang berulang-ulang. 


\section{KESIMPULAN}

Penelitian ini menggunakan metode eksperimen yang melibatkan variabel bebas, yaitu metode latihan drill dan metode latihan taktis dan koordinasi mata-tangan sedangkan sebagai variabel terikatnya adalah keterampilan smash bulutangkis pada atlet sekolahbulutangksiDangauLandak

Berdasarkan hasil analisis data, hasil pengujian hipotesis dan hasil pembahasan penelitian yang telah diperoleh maka dapat dijelaskan beberapa kesimpulan, implikasi penelitian dan saran sebagai berikut:

1. Metode latihan drill memiliki pengaruh yang lebih baik daripada metode latihan taktis terhadap keterampilan smash bulutangkis.

2. Terdapat interaksi antara metode latihan drill dan metode latihan taktis dan koordinasi mata-tangan terhadap keterampilan smash bulutangkis.

3. Metode latihan drill memiliki pengaruh yang lebih baik daripada metode latihan taktis terhadap keterampilan smash bulutangkisbagi atlet yang koordinasi mata-tangantinggi.

4. Metode latihan drill memiliki pengaruh yang lebih baik daripada metode latihan taktis terhadap keterampilan smash bulutangkisbagi atlet yang koordinasi mata-tanganrendah.

\section{Daftar Pustaka}

Aksan, Hermawan. (2011)Mahir Bulutangkis Olahraga Kebangaan . Jakarta: PT. Wadah Ilmu.

Alhusin, Syahril.(2007).Gemar Bermain Bulutangkis. Surakarta :Seti-Aji,

Argasasmita, Husein,DKK., (2007)Teori Kepelatihan Dasar. Jakarta: Lankor,
Arikunto, Suharsimi., (2007)Prosedur Penelitian Suatu Pendekatan Praktik. Jakarta

Atmojo. B. Mulyono (2010)., Tes dan Pengukuran Dalam Pendidikan Jasmani Olahraga Surakarta:UNS Press,

Bompa, Tudor O, G. Gregory Half. Periodizations. Fifth Edition.

Cherly, A Coker.(2014)Motor Learning and Control For Pratitioners. New York: MC.Graw-Hill

Degroot. Neuroanatomi Korelatif Edisi ke21.(2004) Jakarta :Buku Kedokteran EGC

Bahri, Syaiful Djamarah dan Aswan Zain.(2006).Strategi Belajar Mengajar. Jakarta: PT. Rineka Cipta,

Gordon Dan, Coaching Science.(2009) England: Brtihis Library Cataloguing In Publication Data,

Grice, Tony.(2004).Bulutangkis Pentunjuk Praktis Untuk Pemula dan Lanjut. Jakarta:Rajawali Sport,

Herdiansyah, Wildan(2011). Bulutangkis Olahraga Kebanggan. Jakarta: PT.Wadah Ilmu, HardiansyahSefri(2014).

"Pengaruh metode global, elementer dan koordinasi mata-tangan terhadap keterampilan dasar bermain bulutangkis pemain PB SATRIA Kota Baru Kabupaten Pesisir Selatan," Tesis, Universitas Negeri Jakarta

Husdarta.(2010).Psikologi Olahraga. Bandung:Alfabeta, Indrawan,Budi.(2011)Perkembangan Motorik. Tasikmalaya:FIK UNSIL, 
Indrawan ,(2011)Budi dan Sani Gunawan.

Teori Belajar Mengajar Motorik.

Tasikmalaya: FIK UNSIL,

Nur Hamiyah, dan Muhammad Jauhar, (2014).Strategi Belajar Mengajar

Di Kelas Jakarta: Prestasi

Pustakaraya.

Kiram, Yanuar Phil,(2011).Belajar Motorik, Padang:UNP Press,

LesmanaSatriaAgustina.(2015). "Pengaruh Metode Latihan dan Motor Educability Terhadap Keterampilan Dribbling dalam Sepak Bola, "Tesis, Universitas Negeri Jakarta, 2015.

Lubis, Johansyah (2013). Panduan Praktis Penyusunan Program Latihan. Jakarta: PT Rajagrafindo Persada,

Purnama, Santa.K.(2012)kepelatihan Bulutangkis Modern. Surakarta:Yuma Pustaka,

Pearce Evelen, (2009)Anatomi dan Fisiologi untuk Paramedis. Jakarta: PT. Gramedia Pustaka Utama,.

Rahmani, Mikanda. (2014) Buku Super Lengkap Olahraga. Jakarta:Dunia Cerdas,

Sagala, Syaiful. (2009) .Konsep dan Makna Pembelajaran. Bandung:Alfabeta,

Steve Baddeley, (1992) Go and Play Badminton Tecniques and Takticd, London: Stanley Paul \& Co.Lt, ,

Subarjah,(2004), Herman. Pendekatan Keterampilan Taktis dalam Pembelajaran Bulutangkis. DEPDIKNAS

Sukamti.(2007) Pengembangan Motorik. Yogyakarta:DIKTAT UNY,.

Sugiyanto, (1993) Belajar Gerak. Jakarta,.

Surakhmad Winarno (1994), Pengantar Belajar Mengajar, Bandung: Transito,

Sukadiyanto, dan Dangsina Muluk. (2011.)Pengantar Teori Dan

$$
\begin{aligned}
& \text { Metodologi Melatih Fisik. } \\
& \text { Bandung: CV. Lubuk Agung, }
\end{aligned}
$$

Sucipto, Dkk. Sepakbola. Jakarta (2001):

Departemen Pendidikan Nasional, 2000

-----Pendekatan Keterampilan Taktis dalam Pembelajaran Pencak Silat

Konsep \&Metode. Jakarta: Depdiknas,.

Subroto, Toto. (2000)Keterampilan\& Konsep Olahraga di Sekolah, Bandung: UPI

Sugiyono,(2010) Metode Penelitian Pendidikan Pendekatan Kuantitatif, Kualitatif dan $R \& D$, Bandung:Alfabeta,

Syafruddin. (2011) Ilmu Kepelatihan Olahraga. Padang, FIK.UNP,

Syaifuddin (2009), Anatomi Tubuh Manusi Untuk Mahasiswa Keperawatan, Jakarta: Salemba Medika,.

Tangkudung, James dan Wahyuningtyas Puspitosari (2012).. Kepelatihan Olahraga. Jakarta: Cerdas Jaya,

Tohar. (1992) Olahraga Pilihan Bulutangkis. Jakarta,

Usman Tumir Ahmadi.(2010) Kejar Bulutangkis. Jakarta:Rineka Cipta,

White Gregory. (2006)The Physiology Of Training. USA: Elsevier Limited,

Widiastuti. Tes dan Pengukuran Olahraga. (2011) Jakarta: PT. Bumi Timur Jaya,

Yudiana, Yunyun, dan Herman Subarjah, Tite Juliantine (2008). Dasar-Dasar Kepelatihan. Jakarta: Universitas Terbuka,.

Zalindro Ade. (2015) “ Pengaruh Gaya Mengajar dan Koordinasi MataTangan Terhadap Keterampilan Dasar Bermain Bulutangkis", Tesis, Universitas Negeri Jakarta, 